\title{
UJI EFEK TONIK EKSTRAK ETANOL HERBA PEGAGAN (Centella asiatica (L). Urb) PADA MENCIT JANTAN BALB/C
}

\author{
Rini Prastiwi ${ }^{1}$, R.Tjahyadi ${ }^{2}$ Chusun $^{3}$ \\ ${ }^{1)}$ Universitas Muhammadiyah Prof.DR. Hamka \\ ${ }^{2,3)}$ Akademi Farmasi Bhumi Husada Jakarta \\ Email:khanzapras@gmail.com
}

\begin{abstract}
ABSTRAK
Pegagan (Centella asiatica (L). Urb) dikenal secara empiris sebagai obat tradisional untuk mempercepat aktivitas syaraf, meningkatkan daya ingat,dan tonik untuk organ tubuh (hati, ginjal, otak). Efek tonik dapat ditentukan dengan menggunakan metode natatory exhaustion melalui pengamatan efek stimulansia suatu obat pada hewan uji. Tujuan penelitian ini adalah untuk mengetahui efek tonik ekstrak etanol herba pegagan pada mencit jantan $(\mathrm{Balb} / \mathrm{C})$ dan menentukan dosis efektif yang menunjukkan kemampuan mencit untuk mempertahankan diri ketika direnangkan. Penelitian ini menggunakan lima kelompok uji, tiap kelompok terdiri atas lima mencit jantan. Kelompok kontrol positif, kontrol negatif, kelompok dosis I, II dan III ekstrak etanol herba pegagan diberikan masing-masing kafein $100 \mathrm{mg} / \mathrm{kgBB}, \mathrm{CMC}$ 0,5\%, $50 \mathrm{mg} / \mathrm{kg} \mathrm{BB}, 100 \mathrm{mg} / \mathrm{kg} \mathrm{BB}$, dan $150 \mathrm{mg} / \mathrm{kg} \mathrm{BB}$ secara peroral. Pengujian efek tonik dengan metode natatory exhaustion ditunjukkan dengan bertambahnya waktu kemampuan mencit untuk mempertahankan diri ketika direnangkan. Pertambahan waktu tersebut menunjukkan peningkatan daya tahan mencit. Dosis terbaik yang dapat digunakan sebagai tonik adalah $100 \mathrm{mg} / \mathrm{kg} \mathrm{BB}$.
\end{abstract}

Kata kunci : Pegagan, herba, tonik, natatory exhaustion

\section{THE TONIC EFFECT OF ETHANOL EXTRACT PEGAGAN HERBS (Centella asiatica (L). Urb) IN MALE BALB/C MICE}

\begin{abstract}
Pegagan (Centella asiatica (L). Urb) known empiricallay as traditional medicine for accelerating nervous activity, improving memory, and tonic to vital organs (liver, kidneys, brain). Tonic effect can be determined using natatory exhaustion method of stimulantia effect observation a drug on animal test. The aim of this research is to observe the tonic activity of ehanol extract pegagan herb in male mice (Bulb/C) and determined effective dose that shows the ability of mice to defend when swimmed. This research used five groups test, each group are five mice. The positive control group, negative control, does I, II, II groups pegagan herb etanol extract were treated with caffein $100 \mathrm{mg} / \mathrm{kg} \mathrm{BW} 0.5 \% \mathrm{CMC}, 50 \mathrm{mg} / \mathrm{kg}$ $\mathrm{BW}, 100 \mathrm{mg} / \mathrm{kg} \mathrm{BW}$, and $150 \mathrm{mg} / \mathrm{kg} \mathrm{BW}$ gave orally. The tonic effect test used natatory exhaustion method indicate with increasing time of mice ability to defend when swimmed. Added of time showed increase durability of mice. The best dose that can be used as a tonic is $100 \mathrm{mg} / \mathrm{kg} \mathrm{BW}$.
\end{abstract}

Key words : Centella asiatica (L). Urb., Herbs, tonic, natatory exhaustion 


\section{PENDAHULUAN}

Sebagai warisan nenek moyang, tanaman obat sudah dikenal dan digunakan oleh masyarakat Indonesia yang dikenal dengan nama obat tradisional. Peranan obat tradisional masih terasa kuat sebagai pendamping dalam perkembangan kedokteran modern sekarang ini. Sampai sekarang masih banyak obat tradisional yang belum pernah dinilai secara ilmiah baik mengenai efektifitasnya maupun keamanannya.

Melalui penelitian, pengkajian, dan budidaya, tanaman obat herba dapat ditingkatkan untuk bisa dimanfaatkan dalam upaya kesehatan tubuh. Banyak khasiat dari obat tradisional yang memiliki efek tonik bagi tubuh diantaranya adalah pegagan (Centella asiatica (L). Urb). Tanaman ini secara empiris digunakan sebagai tonikum (Sing et al., 2010; Bhavna \& Khatri, 2011). Kandungan utama pegagan yaitu asiatikosida dengan gugus trisakarida terikat pada aglikon asam asiatik. Asiatikosida dan madekasol suatu triterpen saponin dimana sapogeninnya bermanfaat untuk pengobatan. Senyawa lain yaitu brahmosida dan brahminosida yang dapat berkhasiat sebagai uterorelaksan. Isothankunisid dan thankunisid digunakan sebagai antifertilitas yang diujikan pada mencit (Tiwari, et al. 2011).

Penelitian tentang pemanfaatan pegagan dapat menjadi referensi bagi masyarakat dalam menjaga kesehatan dan dapat digunakan sebagai data ilmiah yang melandasi penggunaan herba pegagan sebagai tonikum. Efek tonik yaitu efek yang dapat memacu perbaikan sel-ssel tonus otot. Metode yang digunakan untuk mengetahui efek obat terutama dalam penurunan kontrol syaraf pusat adalah natatory exhaustion (Sambodo, 2009).

Berdasarkan hal tersebut, maka perlu dilakukan penelitian tentang efek tonik herba pegagan dengan metode natatory exhaustion sehingga dalam penggunaan oleh masyarakat dapat dipertanggung jawabkan secara ilmiah.

\section{METODE PENELITIAN}

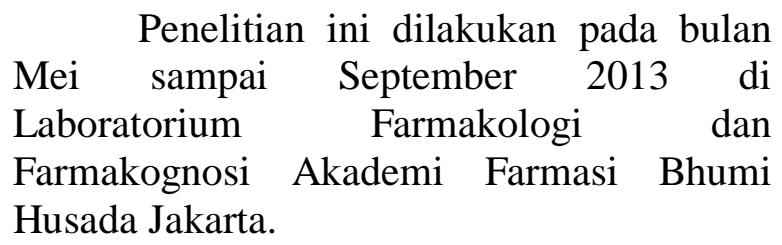

\section{Bahan}

Herba pegagan (Centella asiatica (L.) Urb.) berupa simplisia yang diambil dari Balai Besar Penelitian dan Pengembangan Tanaman Obat dan Obat Tradisional, Tawangmangu, Jawa Tengah, mencit jantan Balb/C.

\section{Alat}

Moisture balance, wadah renang

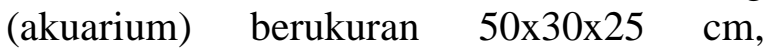
timbangan dan sonde lambung.

\section{Cara Kerja Pembuatan Ekstrak}

Serbuk herba pegagan sebanyak $200 \mathrm{~g}$, direndam dalam 2 liter etanol $96 \%$ selama 3 hari dikocok sekali-kali, kemudian disaring dengan kain batis. Proses diulangi 3 kali dengan pelarut yang sama. Filtrat digabung dan dipekatkan dengan waterbath sampai dihasilkan ekstrak kental.

\section{Penapisan Fitokimia}

Dilakukan pengujian terhadap

alkaloid, flavonoid, triterpenoid dan saponin pada ekstrak kental herba pegagan.

\section{Prosedur Pengujian}

Hewan uji yang digunakan adalah mencit jantan Balb/C sejumlah 25 ekor, berat badan 23-35 gram, umur 8 minggu. Ditimbang dan dibagi menjadi lima kelompok. Setelah itu, setiap mencit diberi perlakuan secara oral dengan sediaan uji. Pembagian kelompoknya adalah, kontrol positif yaitu kafein $100 \mathrm{mg} / \mathrm{kgBB}$, kontrol negatif yaitu hanya diberikan CMC Na $0,5 \%$, perlakuan 1 adalah dosis ekstrak 50 $\mathrm{mg} / \mathrm{kgBB}$, perlakuan 2 adalah dosis ekstrak $100 \mathrm{mg} / \mathrm{kgBB}$, dan perlakuan 3 adalah dosis ekstrak $150 \mathrm{mg} / \mathrm{kgBB}$. Metode yang digunakan adalah natatory exhaustion, 
merupakan metode skrining farmakologi yang dilakukan untuk mengetahui efek obat yang bekerja pada koordinasi gerak, terutama penurunan kontrol syaraf pusat. Uji ini dilakukan terhadap mencit dengan menggunakan wadah renang dengan ketinggian air $18 \mathrm{~cm}$, suhu $20 \pm 0,5^{\circ} \mathrm{C}$ dan pemberian gelombang buatan yang dihasilkan dari sebuah pompa udara, peralatan tambahan yang digunakan harus berada di luar daerah renang, agar tidak mempengaruhi aktivitas renang (Turner, 1965).

\section{Pengamatan Waktu Renang}

Waktu renang sebelum perlakuan adalah lama waktu renang dari hewan uji sebelum mendapat perlakuan dosis uji. Dihitung mulai dari memasukkan hewan uji ke dalam akuarium hingga timbul tanda lelah yang ditandai dengan hewan uji membiarkan kepalanya di bawah permukaan air selama tujuh detik. Kemudian hewan uji diangkat dari wadah renang dan dicatat waktunya. Hewan uji diistirahatkan selama 30 menit, setelah itu diberi perlakuan sediaan peroral. Setelah 30 menit, hewan uji direnangkan kembali dan dicatat waktu lelahnya. Parameter lelah adalah hewan uji tidak menggerakkan kakinya untuk berenang, tubuh mencit tegak lurus dengan permukaan air, ekor tidak bergerak dan membiarkan kepalanya berada di bawah permukaan air selama 7 detik. Penambahan daya tahan atau efek tonikum adalah selisih antara waktu renang sesudah perlakuan dan waktu renang sebelum perlakuan.Data efek tonikum adalah penambahan daya tahan yang diperoleh dari selisih waktu renang pada hewan uji setelah perlakuan dan sebelum perlakuan.

\section{HASIL DAN PEMBAHASAN Ekstraksi dan Penapisan Fitokimia}

Rendemen yang diperoleh dari hasil maserasi yaitu, ekstrak kental etanol sebesar $11,08 \%$. Hasil uji fitokimia ekstrak menunjukkan adanya senyawa alkaloid, triterpenoid dan saponin (Tabel 1). Alkaloid hydrocotylin $\left(\mathrm{C}_{22} \mathrm{H}_{35} \mathrm{NO}_{8}\right)$ diisolasi dari pegagan kering. Saponin ditemukan di seluruh bagian tanaman yaitu centellasaponin B, C, dan D (Matsuda, et al.2001). Senyawa triterpenoid pada pegagan yaitu asiatikosida, centellosida, madekasosida dan asam asiatik (Randriamampionona et al., 2007). Flavonoid pada daun pegagan merupakan senyawa minor seperti 3-glikosilkuersetin, 3glukosilkaempferol dan 7-glikosilkaempferol (Jamil, Qudsia \& Mehboobus, 2007).

Tabel 1. Identifikasi kandungan kimia

\begin{tabular}{llllc}
\hline No. & Kandungan Kimia & \multicolumn{1}{c}{ Pereaksi } & \multicolumn{1}{c}{ Hasil } & Kesimpulan \\
\hline 1 & Alkaloid & Reagen Dragendorff & $\begin{array}{l}\text { Endapan coklat } \\
\text { kemerahan }\end{array}$ & + \\
2. & Flavonoid & Serbuk Mg dalam amil alkohol & $\begin{array}{l}\text { Amil alkohol tidak } \\
\text { berwarna }\end{array}$ & - \\
3. & Saponin & Dikocok kuat dengan air panas & $\begin{array}{l}\text { Buih yang stabil } \\
\text { selama 10 menit }\end{array}$ & + \\
4. & Triterpenoid & Liebermann-Bouchard & Warna merah & + \\
\hline
\end{tabular}

\section{Waktu Renang}

Waktu daya tahan renang mencit jantan pada dosis $50 \mathrm{mg} / \mathrm{kg} \mathrm{BB}, 100 \mathrm{mg} / \mathrm{kg}$ $\mathrm{BB}$ dan $150 \mathrm{mg} / \mathrm{kg} \mathrm{BB}$ dapat dilihat pada Gambar 1. Hasil daya tahan renang yang paling besar adalah kelompok dosis 100 $\mathrm{mg} / \mathrm{kg}$ BB. Uji statistik menggunakan metoda ANOVA menunjukkan ada perbedaan yang bermakna pada daya tahan renang dari 5 kelompok perlakuan $(\mathrm{p}<0,05)$. Hasil uji perbandingan berganda menunjukkan adanya perbedaan yang 
bermakna antara kelompok kontrol negatif dengan kelompok kontrol positif, kelompok dosis $50 \mathrm{mg} / \mathrm{kg} \mathrm{BB}$ dan kelompok dosis 150 $\mathrm{mg} / \mathrm{kg} \quad \mathrm{BB} \quad(\mathrm{p}>0,05)$. Tidak terdapat perbedaan yang bermakna antara kelompok kontrol positif dengan Kelompok Dosis 1 dan Kelompok Dosis $3(\mathrm{p}<0.05)$.

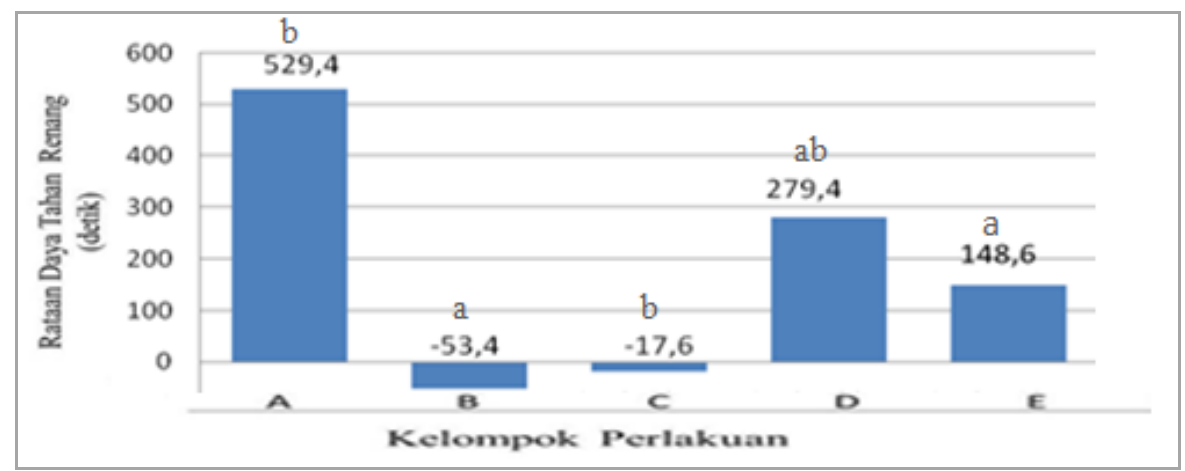

Gambar 1. Gambar Rataan Daya Tahan Renang Tiap Kelompok Perlakuan Keterangan: A=Kelompok Kontrol Positif, B=Kelompok kontrol Negatif, C=Kelompok Dosis 1 (50 mg/kg BB), $\mathrm{D}=$ Kelompok Dosis 2 (100 mg/kg BB), E=Kelompok Dosis 3 (150 mg/kg BB)

Metode Natatory Exhaustion digunakan untuk mengetahui efek obat yang bekerja pada koordinasi gerak terutama kontrol syaraf pusat. Efek stimulan dipengaruhi oleh kondisi fisik hewan uji untuk meningkatkan aktivitas. Peningkatan aktivitas terlihat dari peningkatan kerja secara langsung berupa penambahan waktu lelah hewan uji selama direnangkan dalam tangki berisi air (Turner, 1965).

Saponin diduga memberikan efek tonik pada penelitian ini karena pegagan mengandung senyawa utama saponin dengan asam triterpen dalam bentuk ester dari gula. Asam triterpen yaitu asam asiatik, asam madekasik dan asiatikosida merupakan senyawa yang paling penting untuk pengobatan dan vaskularisasi. Asiatikosida berkhasiat sebagai anksiolitik, antiinflamasi, antioksidan, dan antiulcer (Kimura et al., 2008; Liang et al., 2008). Struktur asiatikosida seperti pada Gambar 2.

Tiga gugus trisakarida yang terikat pada aglikon asam asiatik mengandung gugus OH. Aktivitas antioksidan melalui penangkapan radikal bebas yang berhubungan dengan energi disosiasi pada gugus $\mathrm{OH}$. Kemampuan menangkal radikal bebas berhubungan dengan aktivitas kelarutannya. Melalui model liposom yang terdiri dari bagian lipofil dan hidrofil, gugus gula yang bersifat polar, akan berada dalam fase air. Karena radikal oksigen reaktif juga dihasilkan dalam fase air, maka radikalradikal tersebut akan ditangkap oleh molekul antioksidan yang bersifat polar dan berada dalam fase air. Sehingga oksidasi pada bagian lemak akan berkurang (Zhu, J. M. $\mathrm{Wu}$ and Z. S. Jia. 2005). Semakin kuat aktivitas antioksidan, maka semakin besar kemampuan menstimulasi susunan syaraf pusat. Pada hewan percobaan, kemampuan menstimulasi susunan syaraf pusat berhubungan dengan bertambahnya aktivitas lokomotor (Nikajoo, 2009). Aktivitas lokomotor merupakan aktivitas gerak yang dapat menstimulasi syaraf pada otak (Tiwari, et al. 2010). Tonik dapat digunakan untuk menstimulasi sistem syaraf pusat (Mutschler, E., 1986). Tanaman obat yang mempunyai efek tonik tonik disebut tonikum.

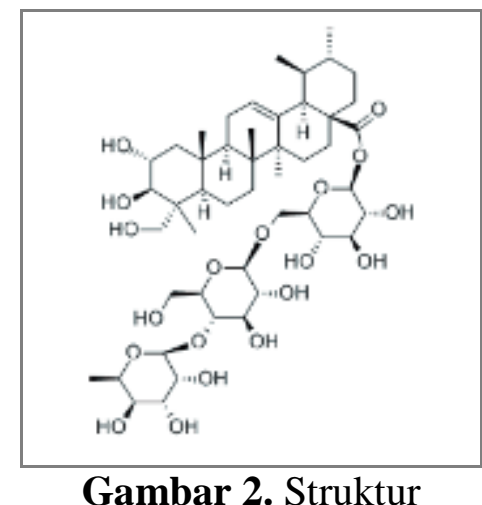

Asiatikosida 


\section{SIMPULAN DAN SARAN Simpulan}

Ekstrak herba pegagan (Centella asiatica (L). Urb) pada dosis $50 \mathrm{mg}$, dosis $100 \mathrm{mg}$, dan dosis $150 \mathrm{mg}$ memiliki potensi sebagai tonikum.

Ekstrak herba pegagan (Centella asiatica (L). Urb) dengan pelarut etanol 96\% pada dosis $100 \mathrm{mg}$ memiliki efek tonikum yang paling efektif, diukur dari daya tahan renang pada Natatory Exhaustion.

\section{Saran}

Perlu dilakukan penelitian lebih lanjut untuk efektifitas dan potensi saponin dalam herba pegagan. Juga perlu dilakukan penelitian yang serupa dengan metode Natatory Exhaustion dengan metode ekstraksi, variasi dosis dan pelarut lainnya.

\section{DAFTAR PUSTAKA}

Bhavna, D., and Khatri, Jyoti. 2011. Centella asiatica: The Elixir of life. International Jurnal of Research in Ayurveda \& Pharmacy. 2 (2): 431-438.

Jamil, S.S., Qudsia, N. and Mehboobus, S. 2007. Centella asiatica (Linn.) Urban A Review. Natural Product Radiance. 6 (2): 158-170.

Kimura, Y., Sumiyoshi, M., Samukawa K., Satake, N., Sakanaka, M. 2008. Facilitating action of asiaticoside at low doses on burn wound repair and its mechanism. Eur J Pharmacol. 3:415423.

Liang, X., Yan, N. H., Si W. C., Wen, J. W., Xu, N., Cui, S., Liu, X.H., Zhang, H., Yue, N.L., Liu, S., Yang, M., Dong, Y. 2008. Antidepressant-like effect of asiaticoside in mice. Pharmacology Biochemistry and Behavior. 3: 444449.

Matsuda, H., Morikawa, T., Ueda, H. and Yoshikawa, M. 2001. Medicinal Foodstuffs .XXVII. Saponin constituents of Gotu Kola (2): Structures of new Ursane- And Olemane-Type Triterpene Oligoglycosides, Centellasaponins B, $\mathrm{C}$, and $\mathrm{D}$, from Centella asiatica cultivated in Sri Lanka, Chem Pharm Bull (Tokyo). 49 (10):1368-1371.

Mutschler, E., 1986. Dinamika Obat, diterjemahkan oleh Widianto, M.B., dan Ranti, A.S., Edisi Kelima, 157 158. Bandung: Penerbit ITB.

Nikajoo, L.T. 2009. Central nervous system depressant activity of alcohol and aqueous root extracts of Pergularia daemia (Forsk.) Chiov, Pharmacolog online. 1. 119-124.

Randriamampionona, D., Diallo, B., Rakotoniriana,F.,Rabemanantsoa, C., Cheuk, K., Corbisier, A.M., Mahillon, J., Ratsimamanga, S., El Jaziri $\mathrm{M}$. 2007. Comparative analysis of active constituents in Centella asiatica samples from Madagascar: application for ex situ conservation and clonal propagation. Fitoterapia. 7-8: 482-489.

Rastogi, R.P. and Mehrotra, B.N. 1960. Compedium of Indian Medicinal Plants. Central Drug Institute Lucknow and Publication and Information Directorate, CSIR, New Delhi: 96

Sambodo, N.W. 2009. Uji Efek Tonik Madu Rambutan Pada Mencit Putih Jantan Dengan Metode Natatory Exhaustion. Skripsi Universitas Muhammadiyah Surakarta.

Singh, S., Gautam, A., Sharma, A. and Batra, A. 2010. Centella asiatica (L.): A plant with immense medicinal potential but threatened. International Journal of Pharmaceutical Sciences Review and Research. 4(2): 9-17.

Tiwari, R.K., Chanda, M.D., B. Murli and A. Agarwal. 2010. HPLC method validation for simultaneous estimation of madecassoside, asiaticoside and asiatic acid in Centella asiatica. J. Chem. Pharm. Res.2 (3): 223-229.

Turner, R.,A, 1965, Screening Methods in Pharmacology, Volume II, Academic Press, New York and London: 76-78.

Zhu, X.Y., J. M. Wu and Z. S. Jia. 2005. Composition and antioxidative activity of polysaccharide from Bergamot. Chem, J. Chinese U. 26 (7): 12641267. 